\title{
The Impact of ASEAN's Rice Trade Barriers on Indonesian Food (Rice) Security
}

\author{
Iwan Hermawan \\ University of Indonesia, Jl. Prof. Dr. Sumitro Djojohadikusumo, Depok, West Java, \\ Indonesia 16424 \\ iwan.hermawan@dpr.go.id
}

\begin{abstract}
In this research, we analysis the impact of ASEAN's rice trade barrier, through tariff and non-tariff measures (NTMs), on Indonesian food (rice) security. To assess whether tariff and NTMs of rice across countries in ASEAN region, Gravity Model and Global Trade Analysis Project (GTAP) Model were applied. All data came from World Bank, Comtrade, World Integrated Trade Solution (WITS), Centre d'Études Prospectives et d'Informations Internationales (CEPII), International Labor Organization (ILO), and GTAPAgg version 9.0. The result of NTMs calculation from Gravity Model and also data of ASEAN Trade in Goods Agreement (ATIGA) schedule as agreement were injected to GTAP Model, to examine the impact of ASEAN's rice trade barrier on Indonesian food (rice) security. A standard GTAP Model was aggregated by 19 sectors and 16 countries/regions. This research showed that (a) imposing ASEAN's rice trade barrier lead to negative effect on Indonesian food (rice) security, (b) comparing between ASEAN's rice NTMs and ATIGA, previous one has higher negative effect on Indonesia food (rice) security, and (c) there is trade-off between ASEAN's rice trade barrier and trade liberalization policy. The government should be careful to impose rice trade barrier as temporary policy to boost rice domestic production.
\end{abstract}

Keywords: Tariff, NTMs, ASEAN, Rice, Food Security.

\section{Introduction}

Food security is a complex issue connected with food trade. Food trade is a critical part of the food security. Food trade is seen as an opportunity to build and/or maintain national food security, through resource re-allocation efficiently and increasing food access [1]. But the other perspective sees it as a threat to stimulate food price fluctuation incident and high food dependency over another country. This debate has happened until today. Then, should we go on, that food trade is still a good option deal with national food security?

However, for trade to improve food security for the greatest number of people, greater international cooperation is necessary [2]. Negotiating trade deals is often difficult, include Doha Round of World Trade Organization (WTO) trade talks began in 2001. The goal is to lower trade barriers, but progress has been slow. There are major differences interesting between rich and developing nations. According to Bezuneh and Yiheyis (2014: 64), for three decades many developing countries have tried to liberalize their food trade but still have low food security level. Now, no wonder many countries still impose food trade barriers. If generally tariff policy is prohibited as WTO commitment, then non-tariff measures (NTMs) become new face as food trade barrier. WTO allows the application of NTMs in particular circumstances. Some expert said that NTMs may effect worse off than tariff barrier. And tariff elimination alone does not create an open market [3]. 
This research focus in ASEAN region as a represent of food trade dynamics when multilateral trade agreements is still difficult embodied than regional one. By under the goal of ASEAN Economic Community (AEC), creating a single market and production base are the central themes of the free flow of goods, services, investment, skilled labour as well as freer flow of capital. The AEC's most significant accomplishment to date lies with the removal of tariff barriers. Information sharing initiatives and the harmonisation of technical and regulatory standards have gained traction, whilst groundwork provided by the rules of origin (ROO) and NTMs has paved the way for future action. Whilst import duties between the ASEAN-6 have been virtually eliminated, it should be noted that tariff reductions for CLMV countries are still underway and have been given a deadline in 2018. ASEAN nations face issues with the common classification of NTMs, which in turn has impeded the rollback and halting of NTMs. Institutional fragmentation has also played a large part in hindering progress [4].

But the global food crisis in 2007/2008 has given an evidence how each ASEAN country deal with between integration purpose as regional food solidarity and national food security, particularly rice. Rice is a major food staple because of 60 percent as calories intake in daily diet menu. Therefore, most of them, include Indonesia, have responded by retreat to autarchy [5] over regional trade liberalization agenda.

Based on Food Act No. 18/2012 give mandate to Indonesia government that domestic food (rice) demand should be fulfilled by self-sufficiency as priority option and by import as third option. [6] warned that government intervenes national food security through rice selfsufficiency program with producer incentive bias. Until now, domestic rice price is still more expensive than other ASEAN countries and the other side rice import always makes "rowdy" year to year. This study tries to analyze the impact of ASEAN's rice trade barrier on Indonesian food security.

\section{Method}

This research used two model, namely Gravity Model and Global Trade Analysis Project (GTAP) Model. For elaborate rice trade barrier, we employed ASEAN Trade in Goods Agreement (ATIGA) schedule for rice tariff as it is and rice NTMs with calculate it via residual approach. Pseudo Poisson Maximum Likelihood (PPML) method was used to handle zero trade flows and also in the presence of heteroscedasticity [7]. NTMs approach based on residual, as practiced by [8], [9]. It is assumed that difference between actual and potential trade flows of the country implies trade barriers. The potential trade flows can be obtained from Gravity estimation. The value of tariff equivalent is very sensitive to the value of elasticity of substitution $(\sigma)$. This study uses value of elasticity from the GTAP database. This approach has been used in a number of estimations of Gravity equations, such as [10], [11].

And the final form of Gravity specification is presented in equation (1), where the subindex $\mathrm{i}$ and $\mathrm{j}$ refer to the exporter and importer country, respectively, whilst $t$ refers to the year:

$$
\begin{aligned}
\mathrm{M}_{\mathrm{ijt}}= & \alpha+\beta_{1} \text { lngdpod }_{\mathrm{it}}+\beta_{2} \text { lndis }_{\mathrm{it}}+ \\
& \beta_{3} \text { lmtro }_{\mathrm{it}} \\
& +\beta_{4} \text { lincm }_{\mathrm{ijt}}+\beta_{5} \mathrm{lpo}_{\mathrm{it}}+\beta_{6} \mathrm{lpd}_{\mathrm{jt}} \\
& +\beta_{7} \text { lvkblo }_{\mathrm{it}}+\beta_{8} \text { lvkbld }_{\mathrm{jt}}+
\end{aligned}
$$

Where:

$\mathrm{M}_{\mathrm{ijt}} \quad$ : imports of country $\mathrm{j}$ from country $\mathrm{i}$ (million USD).

$\operatorname{gdpod}_{\text {it }} \quad$ : ratio between GDP of origin with GDP of destination country (million USD) 


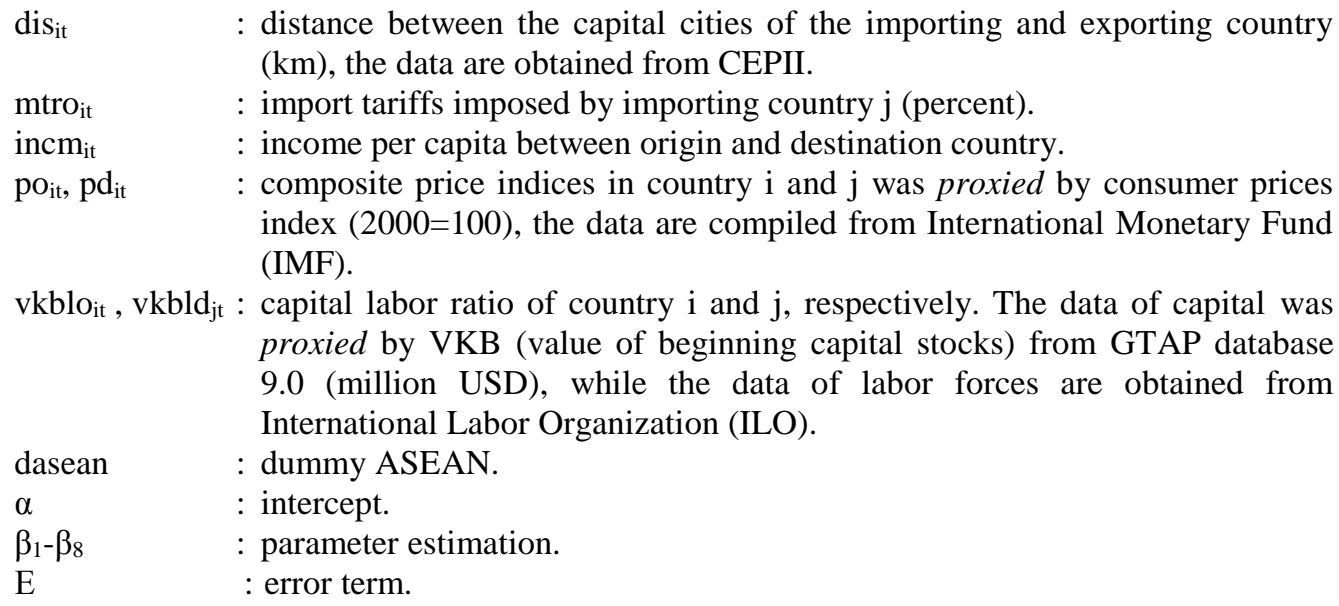
proxied by VKB (value of beginning capital stocks) from GTAP database 9.0 (million USD), while the data of labor forces are obtained from International Labor Organization (ILO).

The second model is GTAP Model. GTAP Model represented regional trade level with its instrument. All specification is standard GTAP model with 19 sectors and 16 countries/regions and running with software RunGTAP 3.61. The basic of that countries/regions aggregation is related with this research topic in ASEAN region. Particularly, data of Myanmar and East Timor are not available in GTAPAgg data. Detail countries/regions aggregation is showed in Appendix 1 and 2. Result running data from Gravity Model was injected to GTAP Model.

Secondary data was used to adjust, construct, and also run those models. Data for running Gravity Model came from World Bank, Comtrade, World Integrated Trade Solution (WITS), International Monetary Fund (IMF), International Labor Organization (ILO), and Centre d'Études Prospectives et d'Informations Internationales (CEPII). And data for running GTAP Model come from GTAPAgg 9.0 [12].

\section{Result}

\subsection{ASEAN Trade Barrier}

Since 1967, several key agreements and actions were adopted in an effort to remove trade barriers and facilitate trade, namely (1) The ASEAN Free Trade Area (AFTA) was signed in 1992, the AFTA detailed the implementation of a Common Effective Preferential Tariff (CEPT) scheme. This applied a 0-5 percent tariff rate to goods traded between ASEAN member states, (2) the AEC Blueprint year 2015 was adopted in 2007, the blueprint outlined strategic measures and also delineated a definitive timeline for the CEPT scheme to be implemented, which further enhanced AFTA, and (3) ATIGA was ratified in 2009, ATIGA expanded on both the [3]. ATIGA also formalized the self-certification and ASEAN Single Window (ASW) concepts for trade facilitation and information sharing [4]. 


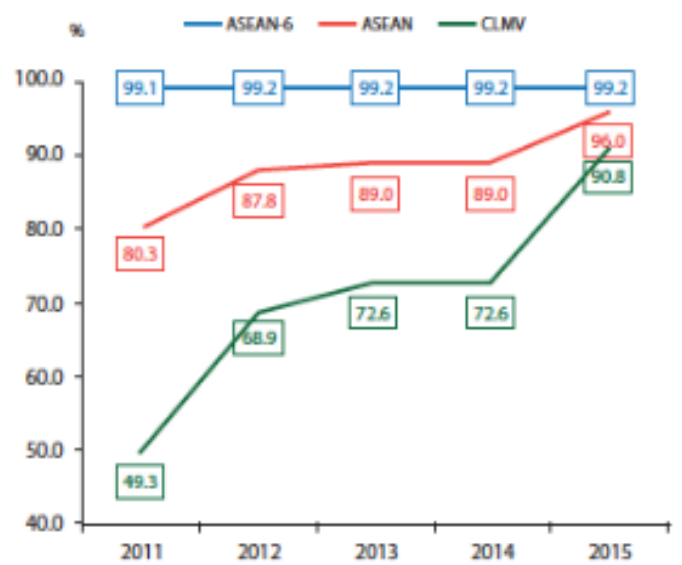

Source: ASEAN Secretariat in Yee, 2016.

Fig. 1. Share of Tariff Lines at Zero Percent in the ATIGA Tariff Schedule.

Significant progress has been made in tariff elimination. Pursuant to the commitments made in the AFTA in 1992, and later in the ATIGA in 2010, Member States have eliminated import duties among themselves by 2010 for the ASEAN-6 (Brunei Darussalam, Indonesia, Malaysia, Philippines, Singapore and Thailand), and by 2015 with flexibility to 2018, for the CLMV. To date (Figure 1), the ASEAN-6 has virtually eliminated their intra-regional tariffs with 99.2 percent of tariff lines at 0 percent. For the CLMV, the figure stands at 90.86 percent giving an ASEAN average of 95.99 percent[3].

ASEAN member countries have made significant progress in the lowering of intraregional tariffs. The fact that tariff liberalisation alone has generally been proven insufficient in providing genuine regional economic integration for many developing countries has drawn further attention to NTMs, of which the WTO disciplines are comparatively weak. The use of NTMs, especially complex technical, sanitary and phytosanitary (SPS) measures, has increased significantly. As the average tariff rates of ASEAN countries decreased from 8.9 percent in 2000 to 4.5 percent in 2015, the number of NTMs had increased from 1,634 measures to 5,975 measures over the same period. The increase of NTMs was notable not only in ASEAN but also around the world, particularly, between 2008 and 2011. The total number of NTMs in the 10 ASEAN countries was 5,975 measures in 2015 of which 33.2 percent of total measures were in the form of SPS, 43.1 percent were Technical Barriers to Trade (TBT), 12.8 percent were export measures, and the rest of 10.9 percent were in the form of various measures [13].

Based on ASEAN.org data, we can see deeply the ASEAN's rice NTMs, especially HS 1006 (rice in the husk, husked (brown) rice, semi-milled or wholly milled rice-whether or not polished, and broken rice). Those data are shown in Table 1, but some country has no enough complete data.

\subsection{Gravity Model Estimation and Calculating NTMs}

Table 1. ASEAN's Rice NTMs

\begin{tabular}{|c|l|l|l|}
\hline No. & \multicolumn{1}{|c|}{ Country } & \multicolumn{1}{|c|}{ NTMs Type } & Description \\
\hline 1. & Indonesia & Monopolistic measures-single & Imports of rice and other basic materials \\
\hline
\end{tabular}




\begin{tabular}{|c|c|c|c|}
\hline & & $\begin{array}{l}\text { channel for imports-State trading } \\
\text { administration }\end{array}$ & \multirow{2}{*}{$\begin{array}{l}\text { can only be carried out by Bulog, } \\
\text { National Logistic Agency } \\
\text { Decree of MIT: 141/MPP/Kep/3/2002: } \\
\text { Import licensing (Nomor Pengenal } \\
\text { Importir Khusus (NPIK) }\end{array}$} \\
\hline & & Automatic import licensing & \\
\hline 2. & $\begin{array}{l}\text { Brunei } \\
\text { Darussalam }\end{array}$ & Technical regulation & ( \\
\hline 3. & Cambodia & (No data) & - \\
\hline 4. & Lao & Automatic import licensing & - \\
\hline \multirow[t]{2}{*}{5.} & \multirow[t]{2}{*}{ Malaysia } & $\begin{array}{l}\text { Import control and single } \\
\text { channel for import (only } \\
\text { BERNAS which is State } \\
\text { Trading Enterprise) }\end{array}$ & $\begin{array}{l}\text { Products can only be imported by } \\
\text { BERNAS which may from time to time } \\
\text { impose some quantitative restriction } \\
\text { measures for price stabilization purpose }\end{array}$ \\
\hline & & $\begin{array}{l}\text { Certificate of approval and } \\
\text { Technical regulations }\end{array}$ & $\begin{array}{l}\text { That the import is accompanied by a } \\
\text { certificate }\end{array}$ \\
\hline 6. & Myanmar & (No data) & - \\
\hline 7. & Philippines & (No data) & - \\
\hline 8. & Singapore & Non-automatic licensing & $\begin{array}{l}\text { Imports of rice are regulated through non } \\
\text { automatic import licensing for price } \\
\text { stability reasons. Licenses for importing } \\
\text { rice are divided into } 2 \text { categories: } \\
\text { Stockpile licenses to ensure that } \\
\text { importers stockpile minimum quantities } \\
\text { of certain types of rice, while ordinary } \\
\text { licenses for other rice varieties }\end{array}$ \\
\hline \multirow{2}{*}{9.} & \multirow{2}{*}{ Thailand } & TRQ and import license & $\begin{array}{l}\text { Imports are subject to the TRQ that } \\
\text { committed under the WTO, with an } \\
\text { objective to secure local farmers' income. } \\
\text { Import license is required by the } \\
\text { Department Foreign and Trade (DFT) }\end{array}$ \\
\hline & & $\begin{array}{l}\text { Standard requirement and } \\
\text { Inspection requirement }\end{array}$ & $\begin{array}{l}\text { Imports should be accompanied with } \\
\text { Phytosanitary certificate and are subject } \\
\text { to inspect at the port of entry under Plant } \\
\text { Quarantine Act. They must also meet } \\
\text { required quality and standard }\end{array}$ \\
\hline 10. & Vietnam & (No data) & - \\
\hline
\end{tabular}

Based on RESET calculation, PPML method was robust for estimating Gravity Model. The RESET test value is 1.13 and it is higher that probability value of Chi2 $(=0.2874)$. Besides being consistent in the presence of heteroscedasticity, this method also provides a natural way to deal with zero values of the dependent variable [7]. Import as dependent variables have some zero value because of not all country occurs rice trade.

In order to see whether all variables can explain the model, the R2 value is needed. R2 value is 0.989 shows that overall model can be explained by its variables 98.9 percent. And in order to see whether each variable can influence the dependent variable, it is able to be checked from $\mathrm{z}$ value comparing with prob. value (significant level). There are 3 (three) variables statistically influence rice import, namely ratio GDP Indonesia and trading partner, distance, and dummy ASEAN as member country. Elaborate of its estimated parameter from Gravity equation didn't do because of Gravity Model only as intermediate calculation process to get rice NTMs. 
The result of tariff equivalents of rice NTMs is presented in Table 2. The country of being used as a benchmark in the tariff equivalence calculation is Singapore against rest of the world. They have the relative low difference value between trade actual and trade potential or we can say that both of them have the small trade barrier or trade restriction in rice.

The value of tariff equivalence on rice NTMs are vary between countries, from 3.43 percent until 41.76 percent. The highest value is Brunei Darussalam and the lowest value is Japan. In Brunei Darussalam, Elizabeth explain there are 58 NTMs regulations containing NTMs, but only 2 (two) that have been notified to the World Trade Organization (WTO), namely the Public Health (Food) Regulations and the Halal Meat Rules. The total number of coded NTMs is 516, affecting 5,613 products (HS code) or 56.6 percent of the total products traded in Brunei, included food.

Various types of NTMs and product specific NTMs are practiced by Japan, which are tariff quota, state trading, and state procurement which are imposed mainly on tobacco, raw sugar and cereal products. [14] said among the countries studied, NTMs coverage for agricultural products is highest in India and followed by Japan. But in this research, Japan relatively has low NTMs value, particular in rice. As reported from [15] research indeed Japan has low until moderate level of NTMs, namely in regulatory philosophy, TBT, SPS, state of information, transport infrastructure, administrative burdens, and consistency of enforcement, exception in level of protectionism. The result maybe is difference because the approach used is deference too.

The staple products, including rice, are some of the most contentious products traded across commodities. The presence of specific government agencies that oversee rice in some economies speaks to how critical grains are to national interests. Similar to fresh produce, the products often need to meet strict SPS and TBT regulations that may go beyond what is necessary to protect consumers. The risk of spoilage is typically lower. On the other hand, many grain traders are charged with purchasing buffer stock or acquiring special import licenses, which carry their own administrative and logistical burdens. While the risk might be comparatively lower, this category typically calls for additional procedures for a business to successfully trade [15].

Table 2. The Tariff Equivalents of Rice NTMs

\begin{tabular}{|c|c|c|c|}
\hline No. & Region & Country & Average \\
\hline \multirow{9}{*}{1.} & \multirow{9}{*}{ ASEAN } & Brunei Darussalam & 41.76 \\
\hline & & Indonesia & 26.07 \\
\hline & & Cambodia & 33.75 \\
\hline & & Lao & 10.22 \\
\hline & & Malaysia & 11.43 \\
\hline & & Philippines & 20.82 \\
\hline & & Singapore & 8.43 \\
\hline & & Thailand & 34.09 \\
\hline & & Viet Nam & 33.24 \\
\hline \multirow{3}{*}{2.} & \multirow{3}{*}{ Middle and East Asia } & China & 21.39 \\
\hline & & Japan & 3.43 \\
\hline & & South Korea & 33.63 \\
\hline 3. & \multicolumn{2}{|l|}{ South Asia } & 25.03 \\
\hline 4. & \multicolumn{2}{|l|}{ Sub-Sahara Africa } & 23.30 \\
\hline 5. & \multicolumn{2}{|l|}{ Middle East Asia } & 26.48 \\
\hline
\end{tabular}




$$
\begin{array}{|l|l|l|}
\hline 6 . & \text { Rest of the World (ROTW) } & 23.02 \\
\hline
\end{array}
$$

Indonesian rice trade opened is relative low level and that value is average range where another ASEAN member country applied. Even Indonesia's value is relatively lower then with rice NTMs of Thailand and Vietnam, as main rice exporter country. Thailand's major NTMs are related to import license, technical measures, and quantity control.

\subsection{Impact of ASEAN's Rice Trade Barrier on Indonesian Food (Rice) Security}

Table 3 presented the impact of ASEAN's rice trade barriers on Indonesian food (rice) security. There is 3 (three) scenario simulations, namely imposing ASEAN's rice NTMs, imposing ATIGA as tariff in rice, and fully rice trade liberalization as controlling scenario

Table 3. The Impact of ASEAN's Rice Trade Barrier on Indonesian Food (Rice) Security

\begin{tabular}{|c|c|c|c|c|c|c|}
\hline \multirow{2}{*}{ No. } & \multirow{2}{*}{ Simulation } & \multicolumn{3}{|c|}{ Availability } & \multirow{2}{*}{ Utility } & \multirow{2}{*}{ Accessibility } \\
\hline & & Production & Export & Import & & \\
\hline 1. & Imposing NTMs & 2.995 & 59.605 & -32.808 & -0.495 & 1.736 \\
\hline 2. & \begin{tabular}{l|} 
Imposing \\
ATIGA
\end{tabular} & 2.756 & 50.281 & -29.116 & -0.311 & 0.686 \\
\hline 3. & $\begin{array}{l}\text { Trade Liberali- } \\
\text { zation }\end{array}$ & -1.027 & -13.184 & 12.430 & 0.164 & -0.599 \\
\hline \multirow{2}{*}{ No. } & \multirow{2}{*}{ Simulation } & \multicolumn{3}{|c|}{ Availability } & \multirow{2}{*}{ Utility } & \multirow{2}{*}{ Accessibility } \\
\hline & & Production & Export & Import & & \\
\hline 1. & Imposing NTMs & 2.995 & 59.605 & -32.808 & -0.495 & 1.736 \\
\hline 2. & $\begin{array}{l}\text { Imposing } \\
\text { ATIGA }\end{array}$ & 2.756 & 50.281 & -29.116 & -0.311 & 0.686 \\
\hline 3. & $\begin{array}{l}\text { Trade Liberali- } \\
\text { zation }\end{array}$ & -1.027 & -13.184 & 12.430 & 0.164 & -0.599 \\
\hline
\end{tabular}

When ASEAN's rice NTMs is imposed, it will make Indonesian food (rice) security become worse off. Rice availability declines because of rice import goes down and a little bit raise in domestic rice production. In terms of rice utilization also declines when rice prices increases. Rice NTMs will add costs and stimulate increase in rice price, so finally rice accessibility will decline. If we compare with imposing ATIGA, then the impact on Indonesian food (rice) security is relatively better than imposing NTMs. It is happened because of NTMs are hard to assess. Different to tariff, which are transparent and accessible via each countries' custom authority, NTMs are often much more hidden [16]

A country with a relatively higher number of measures does not mean it is relatively more protectionist than others. Even if a country has a relatively higher number of percentage of affected products to total products, it does not necessarily mean it will have relatively lower trade than the others. It doesn't mean that all NTMs are benign. Many regulations are poorly designed, failing to protect the public while unnecessarily complicating business. There are several reasons for this. First, the governments know little about incentives and even less about how to design market-based regulations, confusing effective with cumbersome. Second, regulations are often enforced in punitive ways, reflecting the anti-business culture of many 
administrations. Third, NTMs typically span the competencies of several ministries, with no coordination mechanisms to make the necessary trade-offs [13].

Beside both of ASEAN's rice trade barrier, we have tried to compare it with control simulation, which is ASEAN's rice trade fully liberalized. And the result showed that this scenario actually makes Indonesian food (rice) security will be better off that rice availability, rice utility, and rice accessibility improving. But, what needs to be noted here is that simulation 3 pushes to decrease domestic rice production. This is not surprising because Indonesian rice does not have comparative advantage in international market [17].

These conditions are becoming more complicated because of the divergent opinions. Some people views the success of food security is measured by the achievement food (rice) self-sufficiency only and others see the success should be assessed by the achievement food (rice) availability. This is in accordance with the basic explanation by Food and Agriculture Organization (FAO)[18], related to food policy each country in the world are faced with options, namely (1) food self-sufficiency and (2) food self-reliance or "food availability" or food trade.

\section{Conclusion}

ASEAN's rice trade barrier, through tariff or NTMs, has negative effect on Indonesian food (rice) security. This result become an important point how to deal with the rice protectionism that precisely hurt who we protect. While imposing ATIGA and NTMs also stimulate increasing domestic rice production even though in minor.

When we compare it with ASEAN's rice trade liberalization, it will make Indonesian food (rice) security better off. In the other hand, increasing rice availability as one of food security indicator, is supported by increasing rice import. So it will be a hot issue that can be neglected.

There is trade-off between imposing rice trade barrier and fully rice trade liberalization policy. The government should be careful when imposing rice trade barriers as temporary policy to stimulate rice self-sufficiency. However, rice trade liberalization in ASEAN has a potential option to support national food security.

\section{References}

[1] C. Hebebrand, Wedding, and K., "The role of markets and trade in food security. A Report of the CSIS Global Food Security Project. CSIS." Washington DC.

[2] A. Bouët, Laborde, and D., "Building food security through international trade agreements. IFPRI." .

[3] A. S. E. A. N. Secretariat, "A blueprint for growth ASEAN Economic Community 2015: Progress and key achievements. ASEAN Secretariat.” Jakarta.

[4] K. L. Yee, "AEC blueprint 2025 analysis: Paper 2, Liberalisation of the trade in goods," CIMB ASEAN Res. Inst.

[5] T. Slayton, "Rice crisis forensics: How Asian governments carelessly set the world rice market on fire."

[6] P. Simatupang, Timmer, and C. Peter, "Indonesian rice production: Policies and realities," Bull. Indones. Econ. Stud., vol. 44, no. 1, pp. 65-79.

[7] J. M. C. . Silva, Tenreyro, and S., "The log of gravity," Rev. Econ. Stat., vol. 88, no. 4, pp. 641-658.

[8] H. J. Wall, "Using the Gravity Model to estimate the costs of protection," Fed. Reserv. Bank St. Louis Rev., pp. 33-40.

[9] S.-C. Park, "Measuring tariff equivalents in cross-border trade in services."

[10] J. Westerlund, Wilhelmsson, and F., "Estimating the Gravity Model without Gravity 
using panel data," Appl. Econ., vol. 43, pp. 641-649.

[11] T. Akhvlediani, Śledziewska, and K., "Implications of the european integration: Revisiting the hypothesis of 'hub-and-spokes' model," Balt. J. Econ., vol. 17, no. 1, pp. $45-56$.

[12] Fajarina., "Analysis of the Public Relations Function of PT Indofood CBP Sukses Makmur in the Implementation of the Corporate Social Responsibility Program in Makassar," Acta released Vol. 10 No.1 2014., vol. 10 NO 1, no. Corporate Public Relation, p. 1, 2014.

[13] E.R.I.A., "Non-tariff measures in ASEAN. Economic Research Institute for ASEAN and East Asia," in and United Nations Conference on Trade and Development, Jakarta.

[14] U. K. Deb, "Non-tariff barriers in agricultural trade: issues and implications for Least Developed Countries. ARTNeT Policy Brief No. 12. ARTNet and UNESCAP.”.

[15] "Non-tariff barriers in agriculture and food trade in APEC: Business perspectives on impacts and solutions."

[16] E. Yalcin, G. Felbermayr, and L. and Kinzius, Hidden protectionism: Non-tariff barriers and implications for international trade. Munich: Ifo Institute.

[17] D. H. Azahari, Hadiutomo, and K., "Analisis keunggulan komparatif beras Indonesia," Anal. Kebijak. Pertan., vol. 11, no. 1, pp. 61-73.

[18] F.A.O., "The future of food and agriculture, trends and challenges. Food and Agriculture Organization.” Rome. 